\title{
Utilizing pyrolysis GC-MS to characterize organic matter quality in relation to methane production in a thermokarst lake sediment core
}

Joanne Heslop ${ }^{\mathrm{a}^{*}}$, Katey Walter Anthony ${ }^{\mathrm{a}}$, Mingchu Zhang ${ }^{\mathrm{b}}$ 


\section{ABSTRACT}

| Thermokarst (thaw) lakes are an important source of atmospheric $\mathrm{CH}_{4}$; however, few studies have examined the composition and biodegradability of their sediment organic matter (OM). We have quantified the (i) composition of bulk sediment OM (bulk SOM) using pyrolysis gas chromatography-mass spectrometry (GC-MS) and

(ii) statistical relationships between bulk SOM properties and anaerobic incubation $\mathrm{CH}_{4}$ production rate at $3{ }^{\circ} \mathrm{C}$ in sediment core samples from a thermokarst lake system. The study extended through the full vertically-thawed profile $(0-550 \mathrm{~cm})$ of Vault Lake, a small thermokarst lake near Fairbanks, Alaska, USA, and into the permafrost thawing beneath the lake $(551-590 \mathrm{~cm})$. Compared with the underlying mineral-dominated sediments (153-590 cm depth in core), the surface organic-rich sediment horizon $(0-152 \mathrm{~cm})$ had higher $\mathrm{CH}_{4}$ production rate, greater substrate availability indicated by percent organic carbon and total nitrogen, and greater proportions of terrestrially-associated bulk SOM compounds (alkanes, alkenes, lignin products, and phenols and phenolic precursors). Correlation and principal component analyses indicated that $\mathrm{CH}_{4}$ production potential values measured in the core were positively associated with initial substrate availability and terrestrially-derived OM compounds. We observed positive correlation $(\mathrm{p} \leq 0.05)$ between $\mathrm{CH}_{4}$ production and bulk SOM compounds classified as phenols and phenolic precursors, a pattern different from previously observed relationships in natural aquatic anaerobic environments.

\section{Keywords}


methane $\left(\mathrm{CH}_{4}\right)$; soil organic matter (SOM); yedoma; thermokarst lake; lake sediments; anaerobic; carbon (C) mineralization; permafrost; Alaska

\section{Introduction}

Many thermokarst (thaw) lakes formed in permafrost-dominated landscapes have exceptionally high rates of $\mathrm{CO}_{2}$ and $\mathrm{CH}_{4}$ emission (Walter et al., 2007;

Sepulveda-Jauregui et al., 2015; Wik et al., 2016). In rare cases, $\mathrm{CH}_{4}$ emission from these lakes originates from ancient geologic sources (Walter Anthony et al., 2012).

| More commonly, $\mathrm{CH}_{4}$ emissions are the result of modern $\mathrm{C}$ mineralization. The $\mathrm{C}$ utilized in the microbial production of $\mathrm{CH}_{4}$ originates in terrestrial sources such as watershed soils (Kling and Kipphut, 1991), the mobilization of recently-thawed organic C (OC) from permafrost thaw beneath and surrounding the lakes (Walter et al., 2008; Brosius et al., 2012; Kessler et al., 2012), and decomposition of contemporary allocthonous and authochtonous organic matter $(\mathrm{OM})$ in the lakes (Grosse et al., 2013; Walter Anthony et al., 2014; Heslop et al., 2015).

| Several recent studies have begun to increase understanding of sediment OM composition and mineralization in permafrost environments; however, most have

| been limited to examining permafrost C from shallow $(<1 \mathrm{~m})$ soil in terrestrial environments (e.g. White et al., 2002, 2004; Dutta et al., 2006; Treat et al., 2014). Relatively few studies have examined OM biodegradability in the anaerobic incubation of deep (> $5 \mathrm{~m}$ ) permafrost sediments (Wagner et al., 2007; Knoblauch et | al, 2013; Ewing et al., 2015) and there are no studies relating OM quality to 
anaerobic $\mathrm{C}$ mineralization in thermokarst lake sediments and deeper underlying taliks (thaw bulbs).

| Anaerobic C mineralization rate depends on many factors, including substrate availability and quality, $\mathrm{pH}$, moisture, temperature, oxidation-reduction potential and microbial community composition and abundance (Davidson and Janssens, 2006; Waldrop et al., 2010; Grosse et al., 2011; Olefeldt et al., 2013; Treat et al., 2014; Lawrence et al., 2015; Ping et al., 2015). In thermokarst lake I sediments, studies suggest that the majority of $\mathrm{CH}_{4}$ production is concentrated in certain regions. In the lake center, surface sediments, which contain contemporary | allocthonous and authochtonous OM, as well as ancient thawed permafrost OM (Walter Anthony et al., 2014; Farquharson et al., 2016), contribute substantially to total thermokarst lake $\mathrm{CH}_{4}$ production (Kessler et al., 2012; Heslop et al., 2015). The permafrost thaw boundary at the outer extent of a lake's talik, where ancient OM is supplied from thawing permafrost soil to fuel methanogenesis, has also been identified as a region of high $\mathrm{CH}_{4}$ production (Kessler et al., 2012; Walter Anthony et al., 2016). A high rate of $\mathrm{CH}_{4}$ production in sediment zones receiving OM input from lacustrine deposition and thawing permafrost suggests that substrate availability has a large effect on $\mathrm{CH}_{4}$ production potential in thermokarst lakes. However, few studies have characterized substrate availability in these systems.

Past studies using laboratory incubations and/or mass balance approaches to compare sediment $\mathrm{C}$ stock before and after permafrost thaw have shown that the 
labile fraction of recently thawed permafrost $\mathrm{OM}$ is in limited supply. The studies suggest only $5-30 \%$ of $\mathrm{C}$ in mineral permafrost soils is bioavailable over a $100 \mathrm{yr}$ period following thaw under both aerobic and anaerobic decomposition regimes (Shaver et al., 2006; Schädel et al., 2014; Walter Anthony et al., 2014). As the labile fraction of permafrost $\mathrm{OC}$ is utilized, $\mathrm{CH}_{4}$ production rate in thawed permafrost sediments diminishes over time (Kessler et al., 2012; Heslop et al., 2015). In anaerobic talik environments of Siberian thermokarst lakes, the labile fraction of | the permafrost OC pool (28 $\pm 12 \%)$ was estimated from OM mass loss comparison between undisturbed yedoma permafrost soils and taberites (the in situ thawed permafrost soil beneath lakes which are refrozen after the lakes drain); however, there were large regional differences in the size of the labile fraction of permafrost OM based on this method (20-36\%; Walter Anthony et al., 2014). Jones et al. (2016) also observed a ca. $30 \pm 20 \%$ loss of OC from mineral permafrost soils upon thaw in collapse-scar bogs in Alaska, but the amount of time it took to lose this $\mathrm{C}$ remained poorly constrained.

It has been well documented that permafrost $\mathrm{C}$ mineralization rate is positively related to sediment C concentration (e.g. Waldrop et al., 2010; Lee et al., 2012; Knoblauch et al., 2013). Improving knowledge of the quality of the permafrost OC pool would further reduce uncertainty in estimating how thawed permafrost OC would behave in the global C cycle (Hugelius et al., 2012; Strauss et al., 2013; Schädel et al., 2014). Several studies have measured permafrost sediment OC 
quality using laboratory incubations (e.g. Lee et al., 2012; Knoblauch et al., 2013; Schädel et al., 2014). However, incubation periods can last weeks, months, or years and such a labor-intensive method is not well-suited to determining OC quality for a large number of samples. It has been suggested that alternative OM quality | indicators, such as molecular characterization of OM composition, which can be measured in a relatively short period of time and at significantly lower cost than incubation, can be utilized to model $\mathrm{C}$ bioavailability and improve estimates of potential C emissions from thawing permafrost soils (e.g. Dai et al., 2002; White et al., 2002, 2004; Anderson and White, 2006; Paré and Bedard-Haughn, 2013; Treat et al., 2014). Models developed using molecular information from pyrolysis gas chromatography-mass spectrometry (py-GC-MS) have shown potential for estimating permafrost $\mathrm{C}$ mineralization rate values (e.g. Dai et al., 2002; White et al., 2002, 2004; Anderson and White, 2006; Treat et al., 2014), but no study has characterized $\mathrm{OM}$ composition in relation to anaerobic $\mathrm{C}$ mineralization in thermokarst lake sediments and the underlying talik.

Vault Lake $\left(65.0293^{\circ} \mathrm{N}, 147.6987^{\circ} \mathrm{W}\right)$ is a first generation thermokarst lake $\left(3,200 \mathrm{~m}^{2} ; 3.7 \mathrm{~m}\right.$ average depth, $\leq 8.8 \mathrm{~m}$ talik depth below the sediment-water interface) estimated to have formed within the last $400 \mathrm{yr}$ (Heslop et al., 2015). Heslop et al. (2015) quantified $\mathrm{CH}_{4}$ production potential rate values in a Vault Lake sediment core representing the full talik profile in the lake center. In this study, we use the same core to examine sediment OM quality in a boreal zone thermokarst 
lake environment with the objectives of: (i) characterizing deep lake sediment $\mathrm{OM}$

using py-GC-MS and (ii) identifying the strongest predictors of anaerobic permafrost OC biodegradability.

\section{Material and methods}

\subsection{Sample collection and preparation}

।

The collection of the $590 \mathrm{~cm}$ core from the center of the lake during March 2013 was described by Heslop et al. (2015). While Heslop et al. (2015) classified a larger set of sedimentary facies in the core, here we simplified the categorization by recognizing two general horizons: surface organic-rich sediments $(0-152 \mathrm{~cm})$ and underlying mineral sediments $(153-590 \mathrm{~cm})$. After retrieval of the core, the thawed segments were stored in the laboratory at $3{ }^{\circ} \mathrm{C}$ until further analysis; the frozen transitional permafrost core sediments from beneath the talik $(551-590 \mathrm{~cm})$ were stored in the laboratory at $-10{ }^{\circ} \mathrm{C}$ (holding time 61 days until incubation for both thawed and frozen sediments). Sediment slurries (mean $\pm \mathrm{SD}, 269 \pm 253 \mathrm{~g} \mathrm{dw}$ sediment/l water) were prepared for 22 depths along the core and $\mathrm{CH}_{4}$ production potential rate in the slurries, measured at five monthly time steps for up to 175 days, were quantified by Heslop et al. (2015).

Two subsamples of slurry from each depth were analyzed for OM characterization. We oven-dried $\left(105{ }^{\circ} \mathrm{C}, 48 \mathrm{~h}\right)$ subsamples of each slurry, homogenized the dried sediment using a mortar and pestle, and stored them in preashed $\left(450{ }^{\circ} \mathrm{C}, 3 \mathrm{~h}\right)$ sealed glass vials at room temperature. We filtered a second set 
of slurry subsamples through a sterile $0.45 \mu \mathrm{m}$ polyethersulfone membrane filter device (Whatman Puradisc PES) to remove particulate OM and stored the resulting

I solution in sealed, pre-ashed $\left(450{ }^{\circ} \mathrm{C}, 3 \mathrm{~h}\right)$ glass vials in the dark at $3{ }^{\circ} \mathrm{C}$ until analysis.

\subsection{Water-extractable OM quantification}

Dissolved organic C (DOC) concentration of the filtered solution was determined using a total OC analyzer (Aurora 1030; detection limit $2 \mu \mathrm{g} / \mathrm{l}$ ) at the University of Alaska Fairbanks. DOC concentration (mg/l) was divided by the mass of dry sediment per unit volume in the corresponding slurry (g dw/l) to determine soil water-extractable OC (WEOC) content (mg C/g dw). We refer to the dissolved OC fraction as WEOC, as opposed to DOC, for clarity. The term DOC typically refers to a fraction of OC dissolved in situ within soil por water or in aquatic systems, whereas WEOC specifically refers to a fraction of sediment OC dissolved during a laboratory water extraction (Zsolnay, 1996; Corvasce et al., 2006).

\subsection{Bulk SOM characterization}

| Sediment OC $\left(\mathrm{C}_{\text {org }}\right)$, inorganic $\mathrm{C}\left(\mathrm{C}_{\text {inorganic }}\right)$, total $\mathrm{N}\left(\mathrm{N}_{\text {tot }}\right), \mathrm{C}_{\text {org }}: \mathrm{N}_{\text {tot }}$ and $\mathrm{C}_{\text {org }}$ $\left(\delta^{13} \mathrm{C}_{\text {org }}\right)$ and $\mathrm{N}_{\text {tot }}\left(\delta^{15} \mathrm{~N}_{\text {tot }}\right)$ stable isotope ratio values were measured by Heslop et al. (2015) on the homogenized oven dried slurry sediments. Here, we used pyrolysisGC-MS [py-GC-MS; HP 6890 (Agilent Technologies) - HP 5973 (Agilent Technologies)] at the University of Alaska Palmer Research Center, Palmer, 
Alaska, to characterize bulk SOM composition of the same slurry sediment subsamples for 18 depth values along the core. The pyrolyzer temperature was 600 ${ }^{\circ} \mathrm{C}$. The GC carrier gas was run at $10 \mathrm{psi}$ and a constant $30 \mathrm{ml} / \mathrm{min}$ air flow. The GC program was: $35{ }^{\circ} \mathrm{C}(3 \mathrm{~min})$ to $310{ }^{\circ} \mathrm{C}$ (held $\left.5 \mathrm{~min}\right)$ at $15{ }^{\circ} \mathrm{C} / \mathrm{min}$. We conducted duplicate runs and ran $\mathrm{CH}_{3} \mathrm{OH}$ blank following every other sample.

Following White et al. (2004), the 30 most prevalent pyrolysis products in the py-GC-MS dataset were assigned using a spectral library (Wiley 275 library; Figs. S.1, S.2). The relative abundance of each compound was calculated as follows:

where $A_{i}$ is the relative abundance of compound $i(\%), X_{i}$ the spectral peak area of compound $i$, and the sum of all spectral peak areas from the sample (Vancampenhout et al., 2009). Standard deviation in compound relative abundance | between duplicate runs ranged from 0.12-6.29\% (mean 0.85\%). Compounds were classified into nine classes based on their origin: alkanes, alkenes, aromatics and polyaromatics, carboxylic acids, lignin products, lipids, $\mathrm{N}$ compounds, phenols and phenolic precursors, and primary and secondary polysaccharides (Table 1), as defined by White et al. (2002), White et al. (2004), Dai et al. (2002), Vancampenhout et al. (2009), Xu et al. (2009), Yassir and Buurman (2012) and Carr et al. (2013). We then summed the relative abundances of the compounds in each class to obtain the relative proportion (\%) of each compound class in the pyrolysis products. In an independent Fourier transform infrared spectroscopy (FTIR) analysis, we confirmed 
the presence of functional groups that corresponded to the compounds assigned using py-GC-MS (data not shown).

It is important to note that py-GC-MS quantitatively characterizes individual pyrolysis products thermally extracted from the bulk SOM. Since an unknown fraction of SOM is undetected with py-GC-MS, we were not able to determine the absolute concentrations of individual compounds in the bulk SOM or the qualitative characteristics of the average bulk SOM structure (Wang et al., 2011). Therefore, consistent with similar studies using py-GC-MS to characterize terrestrial soils and OM (e.g. Carr et al., 2013; Vancampenhout et al., 2009; Yassir and Burrman, 2012), we report results as the relative abundance of the most prominent pyrolysis product compounds derived from each bulk SOM class to create a "fingerprint" of the SOM. The method characterizes OM in a way which provides a proxy for bulk SOM composition, distinguishes the sediment samples from one another, and allows SOM compounds to be quantified and statistically analyzed (White et al., 2004; Wang et al., 2011). The 30 compounds identified represent $28-40 \%$ of total pyrolysis products detected, but we acknowledge that additional unidentified or undetected compounds could alter the true proportions of each compound class throughout the core.

\subsection{Statistical analysis}

MATLAB (R2016a) software was used. The parameters were tested for normal distribution using the Jarque-Bera test. WEOC concentration, all the bulk

I SOM compound classes measured via py-GC-MS, and $\mathrm{CH}_{4}$ production potential rate 
expressed as $\mu \mathrm{gC} \mathrm{CH}_{4} / \mathrm{g}$ dw/day were not consistent with a normal distribution at the $\alpha=0.05$ level; therefore, differences between core horizons were determined using nonparametric Wilcoxon rank sum tests. We determined relationships between sediment $\mathrm{OM}$ parameters and $\mathrm{CH}_{4}$ production potential rate using nonparametric Spearman's rank correlation coefficients. Differences and correlations were considered statistically significant when $p \leq 0.05(\alpha=0.05)$ or $p \leq$ $0.10(\alpha=0.10)$; the level of significance is reported individually for all results.

| We utilized principal component analysis (PCA) using MATLAB (2016a) software to examine connections and relationships between the different SOM parameters measured for the core. Prior to our PCA, all variables were standardized using z-scores so all transformed variables were centered around 0 with a standard deviation of 1 . Two PCAs (I andII) were run for the standardized geochemical data and the SOM compound class data, respectively.

\section{Results}

\subsection{Bulk SOM compound classes}

Statistical analysis of py-GC-MS data (Wilcoxon rank sum tests) revealed that the organic-rich sediment horizon contained greater proportions of alkanes ( $p$ 0.006; Table S.1; Figs. 1, S.3), alkenes (p 0.006), lignin products ( $\mathrm{p} 0.002$ ), and phenols and phenolic precursors ( $p$ 0.002) than the mineral sediments. All other compound classes did not have statistically significant differences between the 
organic-rich and mineral sediment horizons. Generally, carboxylic acids, N compounds, and primary and secondary polysaccharides represented the largest proportions of the pyrolysis products. Alkanes, alkenes, lignin products, and phenols and phenolic precursors represented the smallest proportions of the pyrolysis products.

\subsection{Effect of bulk SOM properties and WEOC concentration on $\mathrm{CH}_{4}$ production}

| $\mathrm{CH}_{4}$ production potential rate values in the whole core exhibited statistically significant correlation with $\mathrm{C}_{\text {org }}(\mathrm{p} \leq 0.05), \mathrm{C}_{\text {inorganic }}(\mathrm{p} \leq 0.10)$, WEOC $(\mathrm{p} \leq 0.10), \mathrm{N}_{\text {tot }}$ $(p \leq 0.05), C_{\text {org: }} \mathrm{N}_{\text {tot }}(\mathrm{p} \leq 0.10)$ and $\delta^{13} \mathrm{C}_{\text {org }}(\mathrm{p} \leq 0.05$; Table S.2; Figs. 2, S.4).

Relationships between $\mathrm{CH}_{4}$ production potential and $\mathrm{C}_{\text {org }}$, $\mathrm{C}_{\text {inorganic, }}$ WEOC, $\mathrm{N}_{\text {tot }}$ and $\mathrm{C}_{\text {org }}: \mathrm{N}_{\text {tot }}$ were positive and the relationship with $\delta^{13} \mathrm{C}_{\text {org }}$ was negative. We did not observe a statistically significant relationship between $\mathrm{CH}_{4}$ production potential rate and WEOC: $\mathrm{C}_{\text {org }}$ ratios or $\delta^{15} \mathrm{~N}_{\text {tot. }}$.

The proportions of alkanes $(\mathrm{p} \leq 0.05)$, alkenes $(\mathrm{p} \leq 0.05)$, lignin products $(\mathrm{p} \leq$ 0.05), phenolic and phenolic precursors $(\mathrm{p} \leq 0.05)$, and primary and secondary polysaccharides $(\mathrm{p} \leq 0.10)$ for the bulk SOM all positively correlated with $\mathrm{CH}_{4}$ production potential (Fig. S.5). None of the other pyrolysis product classes exhibited a statistically significant relationship with $\mathrm{CH}_{4}$ production potential measured for the core.

\section{3. $P C A$}


Our results from PCA-I (sediment geochemistry) and PCA-II (bulk SOM composition), showed that the first three principal components (PCs) accounted for 81\% (PCA-I: PC1 53\%, PC2 16\%, PC3 12\%; Table S.3; Fig. 3a) and 88\% (PCA-II: PC1 44\%, PC2 29\%, PC3 15\%; Fig. 3b) of the variability in the sediment geochemistry and SOM composition, respectively. According to PCA-I, a little over half the variability was accounted for in $\mathrm{PC1}$, which correlated positively with substrate availability $\left(\mathrm{C}_{\mathrm{org}}, \mathrm{N}_{\mathrm{tot}}\right)$ and the degree of $\mathrm{OM}$ decomposition ( $\left.\delta^{13} \mathrm{C}_{\text {org }}\right)$. PC2, which accounted for $16 \%$ of the variability in PCA-I, corresponded to proportions of algal and land plant $\mathrm{OM}\left(\delta^{15} \mathrm{~N}_{\text {tot }}\right)$, the degree of $\mathrm{OM}$ decomposition $\left(\mathrm{C}_{\text {org: }}: \mathrm{N}_{\text {tot }}\right)$ and WEOC concentration; $\mathrm{PC} 3$, which accounted for $12 \%$ of the total variability in PCA-I, was positively associated with WEOC concentration. In PCA-II, $44 \%$ of the variability was accounted for in PC1, which positively correlated with terrestrially-associated compounds representing the smallest proportions of the bulk SOM (alkanes, alkenes, lignin products, and phenols and phenolic precursors). PC2, accounting for $29 \%$ of the bulk SOM composition variability in PCA-II, correlated positively with the more abundant bulk SOM compounds (carboxylic acids, lipids, and $\mathrm{N}$ compounds). Aromatics and polyaromatics and lipids correlated positively with PC3, which accounted for $15 \%$ of the variability.

In PCA-I, $\mathrm{CH}_{4}$ production potential rate values had the strongest correlation with $\mathrm{PC} 1$, indicating $\mathrm{CH}_{4}$ production had the greatest association with substrate availability as characterized primarily by $\mathrm{C}_{\text {org }}$ and $\mathrm{N}_{\text {tot }}$ concentration. $\mathrm{CH}_{4}$ production also had the strongest correlation with PC1 in PCA-II, indicating it also associated positively with terrestrially-associated compounds (alkanes, alkenes, lignin products, and 
phenols and phenolic precursors). Each of these bulk SOM compound classes also positively correlated $(\mathrm{p} \leq 0.05)$ with $\mathrm{CH}_{4}$ production rate in Spearman's rank analysis.

In both PCA-I and PCA-II, when we plotted the PC1 and PC2 component scores for each sample depth (Fig. 3), we observed separation between samples from the organic-rich sediment horizon $(0-152 \mathrm{~cm}$ depth) and samples from the underlying mineral sediment horizon (153-590 cm depth). The surface organic-rich sediments were characterized by greater substrate availability (higher PC1 scores in PCA-I) and greater proportions of terrestrial bulk SOM compound classes associated positively with $\mathrm{CH}_{4}$ production (higher PC1 scores, PCA-II) compared with the mineral sediments.

\section{Discussion}

\subsection{Bulk SOM composition explained by sediment depositional history}

Different depositional and processing environments in each horizon likely explain why the $\mathrm{OM}$ in the organic-rich sediment horizon was characterized by higher initial substrate levels $\left(\mathrm{C}_{\text {org }}, \mathrm{C}_{\text {inorganic }}\right.$ and $\left.\mathrm{N}_{\text {tot }}\right)$, less decomposed $\mathrm{OM}$ (indicated by lighter $\delta^{13} \mathrm{C}_{\text {org }}$ and higher $\mathrm{C}_{\text {org: }} \mathrm{N}_{\text {tot }}$ ratio; Meyers, 2003; Gundelwein et al., 2007; Schirrmeister et al., 2011) and greater proportions of biolabile SOM compounds (alkanes, alkenes, lignin products, and phenols and phenolic precursors) with relatively short (months to years) residence time (Lorenz et al., 2007; Fenner and Freeman, 2011) vs. the underlying mineral sediment horizon. The organic-rich 
horizon consisted of allochthonous and autochthonous sediments and OM which were exposed to the lake water column, settled on the anoxic lake bottom, and were subsequently buried. Such surface sediment facies have been described for other thermokarst lakes in Canada (Murton, 1996), Siberia (Walter Anthony et al., 2014), | and Alaska (Farquharson et al., 2016). At Vault Lake, radiocarbon dating of macrofossils from the organic-rich horizon suggest rapid sediment accumulation (152 cm in the lake center over ca. $400 \mathrm{yr}$ ) and burial in the anoxic lake bottom environment (Heslop et al., 2015). This, in turn, suggests minimal OM processing and a greater likelihood of preserving higher proportions of biolabile OM fractions.

In contrast, the Vault Lake mineral horizon consisted largely of thawed yedoma sediments originally deposited in a non-lake environment over tens of thousands of years during the late Pleistocene. These yedoma sediments experienced significant deformation from post-depositional slope processes (e.g. landslides) prior to burial during syngeneic permafrost accumulation (Meyer et al., 2008; Schirrmeister et al., 2016). Based on high abundances of low molecular weight DOC compounds found in deep yedoma permafrost cores collected from a nearby location in central Alaska (Ewing et al., 2015), it is possible the silt-rich yedoma permafrost sediments surrounding Vault Lake fostered long term anaerobic OM processing prior to thaw. Therefore, the most biolabile OM fractions in these sediments may have been previously processed in aerobic and/or anaerobic conditions prior to being warmed and thawed beneath the thermokarst lake (Heslop et al., 2015). 


\subsection{Relationships between $\mathrm{CH}_{4}$ production and bulk $\mathrm{SOM}$}

While relationships between sediment geochemical properties $\left(\mathrm{C}_{\text {org }}, \mathrm{C}_{\text {inorganic}}\right.$,

| $\mathrm{N}_{\text {tot }}$, and $\left.\mathrm{C}_{\text {org: }}: \mathrm{N}_{\text {tot }}\right)$ and $\mathrm{CH}_{4}$ production potential are well-documented in prior aerobic and anaerobic permafrost incubation studies (e.g. Lee et al., 2012;

Knoblauch et al., 2013; Treat et al., 2014, 2015) and have been reported for the Vault Lake core (Heslop et al., 2015), here we report for the first time observations of statistically significant positive correlation between $\mathrm{CH}_{4}$ production potential rate and bulk SOM composition of thermokarst lake sediments, specifically: alkanes, alkenes, lignin products, phenols and phenolic precursors, and primary and secondary polysaccharides. Polysaccharides are known to be rapidly degraded by microbes and have been shown to correlate positively with $\mathrm{C}$ mineralization in both aerobic and anaerobic environments (Anderson and White, 2006; White et al., 2002, 2004; Yavitt et al., 2005; Harrysson Drotz et al., 2010; Treat et al., 2014). The remaining bulk SOM compounds which correlated positively with $\mathrm{CH}_{4}$ production in our study are typically more abundant in terrestrial environments (Lorenz et al., 2007; Ward et al., 2013) and were also more abundant $(\mathrm{p} \leq 0.05)$ in the surface organic-rich sediment horizon of the lake core. We note the terrestrially-derived compound classes which positively correlated with $\mathrm{CH}_{4}$ production (alkanes, alkenes, lignin products, and phenols and phenolic precursors) also positively correlated $(\mathrm{p} \leq 0.05)$ with each other (Table S.2). Therefore, $\mathrm{CH}_{4}$ production here may be driven by terrestrially-derived compounds as a unit rather than the individual pyrolysis product compound classes. 
Our study focused on a single lake center core; however, we may expect wide variability in the relationship between $\mathrm{CH}_{4}$ production rate and substrate availability and composition across lake basins. Studies of other thermokarst lakes in Alaska and Siberia have found substantial variability in the thickness of the surface organic-rich horizon across lake basins (Walter Anthony et al., 2014; Farquarson et al., 2016). Closer to the lake margin, the thickness of this horizon decreases and the surface sediments are more heavily influenced by terrestrial vegetation input (Farquharson et al., 2016). The relative contribution of recentlythawed yedoma OM to the vertical profile also increases adjacent to expanding thermokarst margins (Kessler et al., 2012). These spatial variations in OM depositional rate and terrestrial vegetation input may, in turn, influence in situ association between molecular SOM composition and $\mathrm{CH}_{4}$ production.

\section{3. $\mathrm{CH}_{4}$ production associated with phenolic compounds}

In previously studied natural anaerobic ecosystems, phenolic compounds correlated negatively with or inhibited C mineralization (White et al., 2002; Fenner and Freeman, 2011). Here, the abundance of compounds classified as phenols and phenolic precursors correlated positively with $\mathrm{CH}_{4}$ production. To our knowledge, this study is the first observation of the abundance of phenol and phenolic precursor compounds being positively associated with anaerobic $\mathrm{C}$ mineralization in a natural aquatic ecosystem.

Under aerobic conditions (e.g. rivers, dry periods in wetlands), the presence of $\mathrm{O}_{2}$ has been found to cause the removal of phenolic compounds via phenol oxidase 
activity, subsequently removing a barrier to $\mathrm{C}$ mineralization and causing an increase in C mineralization rate (Fenner and Freeman, 2011; Ward et al., 2013; Mann et al., 2014). While anaerobic mineralization of phenolic compounds has not been observed in these natural aquatic ecosystems, anaerobic microbial processing of phenols to $\mathrm{CO}_{2}$ and $\mathrm{CH}_{4}$ has been documented in wastewater treatment studies (e.g. Dwyer et al., 1986; Young and Rivera, 1985; Fang and Zhou, 1999). Since methanogens do not directly metabolize phenolic compounds (Wolfe, 1971), anaerobic conversion of phenolic compounds to $\mathrm{CH}_{4}$ requires a multistep process. Phenolic compounds are initially converted to benzoate $\left(\mathrm{C}_{7} \mathrm{H}_{5} \mathrm{O}_{2}{ }^{-}\right)$, which is subsequently converted into intermediate fatty acids, then acetate $\left(\mathrm{C}_{2} \mathrm{H}_{3} \mathrm{O}_{2}{ }^{-}\right)$and $\mathrm{H}_{2}$, and finally $\mathrm{CH}_{4}$ (Fang and Zhou, 1999). This process requires syntrophic association between phenol-oxidizing bacteria, Methanothrix-like bacteria and $\mathrm{H}_{2}$ utilizing methanogens (Dwyer et al., 1986).

Prior to anaerobic conversion of phenols to $\mathrm{CH}_{4}$, anoxic conditions must be sustained long enough for (i) the syntrophic microbial communities to acclimatize and (ii) redox conditions to allow for phenolic compounds to be reduced without competing electron acceptors such as $\left.\mathrm{NO}_{3}{ }^{-}\right), \mathrm{MnO}_{2}, \mathrm{Fe}^{3+}, \mathrm{SO}_{4}{ }^{2-}$ and $\mathrm{CO}_{2}$ (Young and Rivera, 1985; Dwyer et al., 1986; Fang and Zhou, 1999; Pezeshki and DeLaune, 2012). We suggest the positive association between phenol abundance and I methanogenesis may not have been observed previously in natural systems such as rivers (Ward et al., 2013; Mann et al., 2014) and peatlands (Fenner and Freeman, 2011) because periodic drying and exposure to $\mathrm{O}_{2}$ may prevent such conditions from 
being met. In contrast, sediments in a thermokarst-lake talik are typically exposed to stable, saturated, anaerobic conditions for hundreds to thousands of years (West and Plug, 2008; Kessler et al, 2012), potentially allowing acclimatization of necessary microbial communities and low redox potential necessary to convert phenolic compounds to $\mathrm{CH}_{4}$. We pose this explanation as a hypothesis, because to our knowledge no lab experiments have been conducted to prove it and we did not measure redox potential in our core.

\subsection{Other factors affecting $\mathrm{CH}_{4}$ production}

While our study examined how OM composition affected anaerobic $\mathrm{CH}_{4}$ production in laboratory incubations, it is also important to consider how various additional factors affect $\mathrm{C}$ bioavailability in the field. Given the right physical and/ or chemical conditions, labile $\mathrm{C}$ can be stabilized and made unavailable for $\mathrm{C}$ mineralization and, conversely, recalcitrant $\mathrm{C}$ can be mineralized (von Lützow et al., 2006; Marschner et al., 2008; Kleber, 2010). Furthermore, a fraction of sediment OM can be associated with soil minerals, making it unavailable for decomposition, although studies of permafrost soils suggest much of its soil OM is poorly associated with minerals (Diochon et al., 2013; Höfle et al., 2013). Our characterization of bulk SOM, which we used to determine relationships with $\mathrm{CH}_{4}$ production, did not take these processes into account.

Additional studies have suggested that microbial biomass and diversity also play an important role in determining $\mathrm{C}$ mineralization rate from permafrost sediment (Schimel and Chapin, 2006; Waldrop et al., 2010; Capek et al., 2015). 
Carbon mineralization rate of thawed permafrost sediments correlates with microbial biomass; sediments with low microbial biomass, such as deep permafrost sediments and cryoturbated materials, have a lower rate of $\mathrm{C}$ mineralization upon thaw (Waldrop et al., 2010; Capek et al., 2015). Microbial community composition is also known to play an important role in determining how thawed permafrost $\mathrm{C}$ is processed to greenhouse gases (McCalley et al., 2014), but the influence of permafrost microbial community composition remains poorly understood.

Temperature is also an important control over $\mathrm{C}$ mineralization rate. Anaerobic $\mathrm{CH}_{4}$ production and relationships with bulk SOM characteristics were determined here at an incubation temperature of $3^{\circ} \mathrm{C}$. This value is near the mean annual temperature of shallow sediment depths measured at Vault Lake (mean annual temperate $3.57^{\circ} \mathrm{C}$; Heslop et al., 2015), but observed temperature in two profiles in the Vault Lake talik ranged from -0.40 to $14.00{ }^{\circ} \mathrm{C}$ during May 2013 to December 2014 (Heslop et al., 2015). The temperature deviation from the annual mean is indicative of deviation in actual $\mathrm{C}$ mineralization rate throughout the talik sediments compared with $\mathrm{C}$ mineralization rate in our $3{ }^{\circ} \mathrm{C}$ incubations. It is also possible that the relationship between anaerobic $\mathrm{CH}_{4}$ production and SOM characteristics changes as temperature varies. For example, Dai et al. (2002) found that polysaccharides were the most bioreactive compounds in aerobic incubations at 
$4^{\circ} \mathrm{C}$, but at $25^{\circ} \mathrm{C}$ they exhibited weaker correlation with $\mathrm{C}$ mineralization rate and more recalcitrant fractions of OM such as lignin were consumed. Anderson and White (2006) also observed lignin utilization at higher temperature $\left(20^{\circ} \mathrm{C}\right)$ in anaerobic conditions, but did not incubate samples at other temperatures for comparison. These differences may be due to compound-specific microbial decomposition activation energies, which are available in warmer temperatures but possibly inhibiting in colder temperatures (Knorr et al., 2005; Davidson and Janssens, 2006; Conant et al., 2008). It is also possible these changes in substrate consumption at different temperatures are due to changes in microbial metabolism and active microbial communities (Allen et al., 2005; Waldrop et al., 2010; YvonDurocher et al., 2012). For instance, Dai et al (2002) found that phenolic compounds correlated positively with aerobic $\mathrm{C}$ mineralization rate at $4^{\circ} \mathrm{C}$ but correlated negatively with aerobic $\mathrm{C}$ mineralization rate at $25^{\circ} \mathrm{C}$, possibly indicative of different microbial communities utilizing different fractions of soil OM at different temperatures. Therefore, when using $\mathrm{OM}$ characteristics to predict $\mathrm{C}$ biolability in situ, it is important to consider how these relationships change with temperature and to take the changes into account.

\section{Conclusions}


Our results suggest $\mathrm{CH}_{4}$ production potential rate in the Vault Lake sediment core is positively associated with substrate availability $\left(\mathrm{C}_{\mathrm{org}}, \mathrm{N}_{\mathrm{tot}}\right)$ and terrestrially-derived OM compounds (alkanes, alkenes, lignin products, and phenols and phenolic precursors). Furthermore, we used PCA to show sediments from the lake core could be characterized into two distinct horizons (surface organic-rich sediments and mineral sediments) based on their bulk SOM characterization and $\mathrm{CH}_{4}$ production potential rate. Compared with the mineral sediments, the organicrich sediment horizon had: a higher level initial substrate, indicated by higher levels of $\mathrm{C}_{\text {tot }}, \mathrm{C}_{\text {org }}$, and $\mathrm{N}_{\text {tot }}$; less decomposed $\mathrm{OM}$, indicated by higher $\mathrm{C}_{\text {org: }}: \mathrm{N}_{\text {tot }}$ values and lighter $\delta^{13} \mathrm{C}_{\text {org }}$ values; greater influence of terrestrial $\mathrm{OM}$, indicated by greater proportions of alkanes, alkenes, lignin products, and phenols and phenolic precursors in the bulk SOM, and higher $\mathrm{CH}_{4}$ production rate.

\section{Author Contributions}

J.K.H. devised the study, collected and analyzed the data, and wrote the manuscript. K.W.A. and J.K.H. conducted fieldwork. All authors performed lab work and commented on data analysis and manuscript composition.

\section{Acknowledgements}

We thank P. Anthony, S. Billings, A. Bondurant, J. Guerard, N. Haubenstock, T. Howe, L. Oliver, K. Martinez-Cruz, A. Sepulveda-Jauregui, M. Short, A. Soria, B. Van Veldhuizen and M. Wooller for assistance in data collection and/or analysis and S. Skidmore for granting access to Vault Lake. We also thank the anonymous 
reviewers for their helpful feedback on both this version and an earlier version of this manuscript. Funding for J.K.H. and K.W.A. was provided by DOE DESC0006920, NSF OPP-1107892, and ARC-1304823; additional funding for J.K.H. was provided under STAR Fellowship Assistance agreement no. FP-91762901-0 awarded by the US Environmental Protection Agency (EPA). The publication has not been formally reviewed by the EPA. The views expressed are solely those of the authors and the EPA does not endorse any products or commercial services mentioned.

Associated Editor - P.A. Meyers 


\section{References}

Allen, A.P., Gillooly, J.F., Brown, J.H., 2005. Linking the global carbon cycle to individual metabolism. Functional Ecology 19, 202-213.

Andersen, S., White, D.M., 2006. Determining soil organic matter quality under anaerobic conditions in arctic and subarctic soils. Cold Regions Science and Technology 44, 149-158.

Brosius, L.S., Walter Anthony, K.M., Grosse, G., Chanton, J.P., Farquharson, L.M., Overduin, P.P., 2012. Using the deuterium isotope composition of permafrost meltwater to constrain thermokarst lake contributions to atmospheric $\mathrm{CH}_{4}$ during the last deglaciation. Journal of Geophysical Research Biogeosciences 117, G01022.

Čapek, P., Diáková, K., Dickopp, J.-E., Bárta, J., Wild, B., Schnecker, J., Alves, R.J.E., Aiglsdorfer, S., Guggenberger, G., Gentsch, N., Hugelius, G., Lashchinsky, N., Gittel, A., Schleper, C., Mikutta, R., Palmtag, J., Shibistova, O., Urich, T., Richter, A., Šantrůčková, H., 2015. The effect of warming on the vulnerability of subducted organic carbon in arctic soils. Soil Biology and Biochemistry 90, 19-29.

Carr, A., Boom, A., Chase, B., Meadows, M., Roberts, Z., Britton, M., 2013. Biomescale characterization and differentiation of semi-arid and arid zone soil organic matter compositions using pyrolysis-GC/MS analysis. Geoderma 200, 189-201. 
Conant, R.T., Drijber, R.A., Haddix, M.L., 2008. Sensitivity of organic matter decomposition to warming varies with its quality. Global Change Biology 14, 868-877.

Corvasce, M., Zsolnay, A., D’Orazio, V., Lopez, R., Mioano, T.M., 2006.

Characterization of water extractable organic matter in a deep soil profile. Chemosphere 62, 1583-1590.

Dai, X.Y., White, D.M., Ping, C.-L., 2002. Comparing bioavailability in five Arctic soils by pyrolysis-gas chromatography/mass spectrometry. Journal of Analytical and Applied Pyrolysis 62, 249-258.

Davidson, E.A., Janssens, I.A., 2006. Temperature sensitivity of soil carbon decomposition and feedbacks to climate change. Nature 440, 165-173.

Diochon, A., Gregorich, E.G., Tarnocai, C., 2013. Evaluating the quantity and biodegradability of soil organic matter in some Canadian Turbic Cryosols. Geoderma 202-203, 82-87.

Dutta, K., Schuur, E.A.G., Neff, J.C., Zimov, S.A., 2006. Potential carbon release from permafrost soils of Northeastern Siberia. Global Change Biology 12, $2336-2351$.

Dwyer, D.F., Krumme, M., Boyd, S.A., Tiedje, J.M., 1986. Kinetics of phenol biodegradation by an immobilized methanogenic consortium. Applied and Environmental Microbiology 52, 345-351.

Ewing, S., O’Donnell, J., Aiken, G., Butler, K., Butman, D., Windham-Myers, L., Kanevskiy, M.Z., 2015. Long-term anoxia and release of ancient, labile 
carbon upon thaw of Pleistocene permafrost. Geophysical Research Letters $42,10,730-10,738$.

Fang, H., Zhou, G.M., 1999. Interactions of methanogens and denitrifiers in degradation of phenols. Journal of Environmental Engineering 125, 57-63.

Farquharson, L., Walter Anthony, K., Bigelow, N., Edwards, M., Grosse, G., 2016. Facies analysis of yedoma thermokarst lakes on the northern Seward Peninsula, Alaska. Sedimentary Geology 340, 25-37.

Fenner, N., Freeman, C., 2011. Drought-induced carbon loss in peatlands. Nature Geoscience 4, 895-900.

Grosse, G., Harden, J., Turetsky, M., 2011. Vulnerability of high-latitude soil organic carbon in North America to disturbance. Journal of Geophysical Research Biogeosciences 116, G00K06.

Grosse, G., Jones, B., Arp, C., 2013. Thermokarst lakes, drainage, and drained basins In: Shroder, J. F. (Ed.), Treatise on Geomorphology. Academic Press, San Diego, pp. 325-353.

Gundelwein, A., Müller-Lupp, T., Sommerkorn, M., Haupt, E.T.K., Pfeiffer, E.-M., Wiechmann, H., 2007. Carbon in tundra soils in the Lake Labaz region of arctic Siberia. European Journal of Soil Science 58, 1164-1174.

Harrysson Drotz, S., Sparrman, T., Nilsson, M.B., 2010. Both catabolic and anabolic heterotrophic microbial activity proceed in frozen soils. Proceedings of the National Academy of Sciences of the United States of America 107, 21046-21051. 
Heslop, J.K., Walter Anthony, K.M., Sepulveda-Jauregui, A., Martinez-Cruz, K., Bondurant, A., Gross,e G., 2015. Thermokarst lake methanogenesis along a complete talik profile. Biogeosciences 12, 4317-4331.

Höfle, S., Rethemeyer, J., Mueller, C.W., John, S., 2013. Organic matter composition and stabilization in a polygonal tundra soil of the Lena Delta. Biogeosciences 10, 3145-3158.

Hugelius, G., Routh, J., Kuhry, P., Crill, P., 2012. Mapping the degree of decomposition and thaw remobilization potential of soil organic matter in discontinuous permafrost terrain. Journal of Geophysical Research Biogeosciences 117, G02030.

Jones, M., Harden, J., O’Donnell, J., Manies, K., Jorgenson, T., Treat, C., Ewing, S., 2016. Rapid carbon loss and slow recovery following permafrost thaw in boreal peatlands. Global Change Biology, doi: 10.1111/gcb.13403.

Kessler, M.A., Plug, L.J., Walter Anthony K.M., 2012. Simulating the decadal- to millennial-scale dynamics of morphology and sequestered carbon mobilization of two thermokarst lakes in NW Alaska. Journal of Geophysical Research Biogeosciences 117, G00M06.

Kleber, M., 2010. What is recalcitrant soil organic matter? Environmental Chemistry 7, 320-332.

Kling, G.W., Kipphut, G.W., 1991. Arctic lakes and streams as gas conduits to the atmosphere: implications for tundra carbon budgets. Science 251, 298-301. 
Knoblauch, C., Beer, C., Sosnin, A., Wagner, D., Pfeiffer, E.-M., 2013. Predicting long-term carbon mineralization and trace gas production from thawing permafrost of Northeast Siberia. Global Change Biology 19, 1160-1172.

Knorr, W., Prentice, I.C., House, J.I., Holland, E.A., 2005. Long-term sensitivity of soil carbon turnover to warming. Nature 433, 298-301.

Lawrence, D.M., Koven, C.D., Swenson, S.C., Riley, W.J., Slater, A.G., 2015.

Permafrost thaw and resulting soil moisture changes regulate projected highlatitude $\mathrm{CO}_{2}$ and $\mathrm{CH}_{4}$ emissions. Environmental Research Letters 10, 094011.

Lee, H., Schuur, E.A.G., Inglett, K., Lavoie, M., Chanton. J., 2012. The rate of permafrost carbon release under aerobic and anaerobic conditions and its potential effects on climate. Global Change Biology 18, 515-527.

Lorenz, K., Lal, R., Preston, C., Nierop, K., 2007. Strengthening the soil organic carbon pool by increasing contributions from recalcitrant aliphatic bio(macro)molecules. Geoderma 142, 1-10.

Mann, P., Sobczak, W., LaRue, M., Bulygina, E., Davydova, A., Vonk, J., 2014. Evidence for key enzymatic controls on metabolism of Arctic river organic matter. Global Change Biology 20, 1089-1100.

Marschner, B., Brodowski, S., Dreves, A., 2008. How relevant is recalcitrance for the stabilization of organic matter in soils? Journal of Plant Nutrition and Soil Sciences 171, 91-110. 
McCalley, C.K., Woodcroft, B.J., Hodgkins, S.B., Wehr, R.A., 2014. Methane dynamics regulated by microbial community response to permafrost thaw. Nature 514, 478-481.

Meyer, H., Yoshikawa, K., Schirrmeister, L., Andreev, A., 2008. The Vault Creek Tunnel (Fairbanks Region, Alaska): A Late Quaternary Palaeoenvironmental Permafrost Record. Ninth International Conference on Permafrost, 11911196, University of Alaska Fairbanks, Fairbanks, Alaska, USA, 29 June to 03 July, 2008.

Meyers. P.A., 2003. Applications of organic geochemistry to paleolimnological reconstructions: a summary of examples from the Laurentian Great Lakes. Organic Geochemistry 34, 261-289.

Murton, J.B., 1996. Thermokarst-lake-basin sediments, Tuktoyaktuk Coastlands, western arctic Canada. Sedimentology 43, 737-760.

Olefeldt, D., Turetsky, M., Crill, P., McGuire, D., 2013. Environmental and physical controls on northern terrestrial methane emissions across permafrost zones. Global Change Biology 19, 589-603.

Paré, M.C., Bedard-Haughn, A., 2013. Soil organic matter quality influences mineralization and GHG emissions in cryosols: a field-based study of sub- to high Arctic. Global Change Biology 19, 1126-1140.

Pezeshki, S.R., DeLaune, R.D., 2012. Soil oxidation-reduction in wetlands and its impact on plant functioning. Biology 1, 196-221. 
Ping. C.-L., Jastrow, J.D., Jorgenson, M.T., Michaelson, G.J., Shur, Y.L., 2015.

Permafrost soils and carbon cycling. Soil 1, 147-171.

Schädel, C., Schuur, E.A.G., Bracho, R., 2014. Circumpolar assessment of permafrost $\mathrm{C}$ quality and its vulnerability over time using long-term incubation data. Global Change Biology 20, 641-652.

Schimel, J.P., Chapin III, F.S., 2006. Microbial processes in the Alaskan boreal forest. In: Chapin, F. S., Oswood, M.W. (Eds.), Alaska's Changing Boreal Forest. Oxford University Press, New York, pp. 227-240.

Schirrmeister, L., Grosse, G., Wetterich, S., Overduin, P., Strauss, J., Schuur, E.A.G., 2011. Fossil organic matter characteristics in permafrost deposits of the northeast Siberian Arctic. Journal of Geophysical Research 116, G00M02.

Schirrmeister, L., Meyer, H., Andreev, A., Wetterich, S., Kienast, F., Bobrov, A., Fuchs, M., Sierralta, M., Herzschuh, U., 2016. Late Quaternary paleoenvironmental records from the Chatanika River valley near Fairbanks (Alaska). Quaternary Science Reviews, doi:10.1016/j.quascirev.2016.02.009.

Sepulveda-Jauregui, A., Walter Anthony, K.M., Martinez-Cruz, K., Greene, S., Thalasso, F., 2015. Methane and carbon dioxide emissions from 40 lakes along a north-south latitudinal transect in Alaska. Biogeosciences, 12, 3197-3223.

Shaver, G.R., Giblin, A.E., Nadelhoffer, K.J., Thieler, K.K., Downs, M.R., Laundre, J.A., Rastetter, E.B., 2006. Carbon turnover in Alaskan tundra soils: effects 
of organic matter quality, temperature, moisture and fertilizer. Journal of Ecology 94, 740-753.

Strauss, J., Schirrmeister, L., Grosse, G., Wetterich, S., Ulrich, M., Herzschuh, U., Hubberten, H.-W., 2013. The deep permafrost carbon pool of the Yedoma Region in Siberia and Alaska. Geophysical Research Letters 40, 6165-6170.

Treat, C.C., Wollheim, W.M., Varner, R.K., 2014. Temperature and peat type control $\mathrm{CO}_{2}$ and $\mathrm{CH}_{4}$ production in Alaskan permafrost peats. Global Change Biology 20, 2674-2686.

Treat, C.C., Natali, S.M., Ernakovich, J., Iversen, C.M., Lupascu, M., McGuire, A., 2015. A pan-Arctic synthesis of $\mathrm{CH}_{4}$ and $\mathrm{CO}_{2}$ production from anoxic soil incubations. Global Change Biology 21, 2787-2803.

Vancampenhout, K., Wouters, K., Vos, B., Buurman, P., Swennen, R., Deckers, J., 2009. Differences in chemical composition of soil organic matter in natural ecosystems from different climatic regions - A pyrolysis-GC/MS study. Soil Biology and Biochemistry 41, 568-579.

von Lützow, M., Kögel-Knabner, I., Ekschmitt, K., 2006. Stabilization of organic matter in temperate soils: mechanisms and their relevance under different soil conditions-a review. European Journal of Soil Science 57, 426-445.

Wagner, D., Gattinger, A., Embacher, A., 2007. Methanogenic activity and biomass in Holocene permafrost deposits of the Lena Delta, Siberian Arctic and its implication for the global methane budget. Global Change Biology 13, 1089-1099. 
Waldrop, M.P., Wickland, K.P., White III, R., Berhe, A.A., Harden, J.W., Romanovsky, V.E., 2010. Molecular investigations into a globally important carbon pool: permafrost-protected carbon in Alaskan soils. Global Change Biology 16, 2543-2554.

Walter, K.M., Edwards, M., Grosse, G., Zimov, S.A., Chapin, F.S., 2007. Thermokarst lakes as a source of atmospheric $\mathrm{CH}_{4}$ during the last deglaciation. Science 318, 633-636.

Walter, K.M., Chanton, J.P., Chapin, F.S., Schuur, E.A.G., Zimov, S.A., 2008. Methane production and bubble emissions from arctic lakes: Isotopic implications for source pathways and ages. Journal of Geophysical Research Biogeosciences 113, G00A08.

Walter Anthony, K., Anthony, P., Grosse, G., Chanton, J., 2012. Geologic methane seeps along boundaries of Arctic permafrost thaw and melting glaciers. Nature Geoscience 5, 419-426.

Walter Anthony, K.M., Zimov, S.A., Grosse, G., Jones, M.C., Anthony, P.M., Chapin III, F.S., 2014. A shift of thermokarst lakes from carbon sources to sinks during the Holocene epoch. Nature 511, 452-456.

Walter Anthony, K.M., Daanen, R., Anthony, P., Grosse, G., Ping, C.-L., 2016. Ancient methane emissions from permafrost thaw in arctic lakes c. 1950-2010. Nature Geosciences, in press. 
Wang, J.J,, Dodla, S.K., He, Z., 2011. Application of analytical pyrolysis-mass spectrometry in characterization of animal manure. In: Z. He (Ed.), Environmental Chemistry of Animal Manure. Nova Science Publishers, NY, pp. 3-24.

Ward, N.D., Keil, R.G., Medeiros, P.M., Brito, D.C., 2013. Degradation of terrestrially derived macromolecules in the Amazon River. Nature Geoscience $6,530-533$.

West, J.J., Plug, L.J., 2008. Time-dependent morphology of thaw lakes and taliks in deep and shallow ground ice. Journal of Geophysical Research 113, F01009.

White, D., Garland, D.S., Dai, X.Y., Ping, C.-L., 2002. Fingerprinting soil organic matter in the arctic to help predict $\mathrm{CO}_{2}$ flux. Cold Regions Science and Technology 35, 185-194.

White, D.M., Garland, D.S., Ping, C.-L., Michaelson, G., 2004. Characterizing soil organic matter quality in arctic soil by cover type and depth. Cold Regions Science and Technology 38, 63-73.

Wik, M., Varner, R., Walter Anthony, K.M., MacIntyre, S., Bastviken, D., 2016. Climate-sensitive northern lakes and ponds are critical components of methane release. Nature Geoscience 9, 99-105.

Wolfe, R.S., 1971. Microbial formation of methane. Advanced Microbial Physiology, $6,107-146$. 
Xu, C., Guo, L., Ping, C.-L., White, D., 2009. Chemical and isotopic characterization of size-fractionated organic matter from cryoturbated tundra soils, northern Alaska. Journal of Geophysical Research 114, G03002.

Yassir, I., Buurman, P., 2012. Soil organic matter chemistry changes upon secondary succession in Imperata Grasslands, Indonesia: A pyrolysis-GC/MS study. Geoderma 173, 94-103.

Yavitt, J.B., Williams, C., Wieder. R., 2005. Soil chemistry versus environmental controls on production of $\mathrm{CH}_{4}$ and $\mathrm{CO}_{2}$ in northern peatlands. European Journal of Soil Science 56, 169-178.

Young, L.Y., Rivera, M.D., 1985. Methanogenic degradation of four phenolic compounds. Water Research, 19, 1325-1332.

Yvon-Durocher, G., Caffrey, J.M., Cescatti, A., Dossena, M., 2012. Reconciling the temperature dependence of respiration across timescales and ecosystem types. Nature 487, 472-476.

Zsolnay, A., 1996. Dissolved humus in soil waters. In: Piccolo, A. (Ed.), Humic Substances in Terrestrial Ecosystem. Elsevier, Amsterdam, pp. 171-223. 


\section{Tables and Table Captions}

\section{Table 1}

The 30 most prevalent bulk SOM pyrolysis products identified using py-GC-MS, categorized into nine compound classes.

\begin{tabular}{|c|c|}
\hline Class & Pyrolysis product \\
\hline Alkanes & $\begin{array}{l}\text { 2-Trifloroacetoxypentadecane }{ }^{a, b, c} \\
\text { 3-Trifluoroacetoxytridecane }{ }^{a, b, c} \\
\text { 2,6,10-Trimethyltetradecane a,b,c } \\
\text { Decane }^{a, b, c} \\
\text { Trifluoroactoxydodecane } \\
\text { a,b,c }\end{array}$ \\
\hline Alkenes & 3-Undecene * \\
\hline $\begin{array}{l}\text { Aromatics and } \\
\text { polyaromatics }\end{array}$ & $\begin{array}{l}\text { 2,3-Dimethylhylhydroquinone * } \\
\text { Benzene, cyclobutyl- d,e,f } \\
\text { Benzene, cyclopropylidenemethyl d,e,f } \\
\text { Naphthalene d,f } \\
\text { Toluene a,b,c,d,f }\end{array}$ \\
\hline Carboxylic acids & $\begin{array}{l}\text { 1-Hydroxy-2-pentanone a,b,c } \\
\text { 2-Oxetanone, 4,4-dimethyl- }{ }^{*} \\
\text { 8.11-Octadecadiynois acid, methyl ester }{ }^{\text {e }} \\
\text { Butanal, 3-hydroxy }{ }^{*}\end{array}$ \\
\hline Lignin products & Phenol, 4-ethyl- a,b,c \\
\hline Lipids & $\begin{array}{l}\text { 1-Eicosene } \\
\text { 1-Tetradecene } \\
\text { 3-Tetradecene, }(\mathrm{Z})-\text { a,b,c } \\
\text { Heptanal }^{*}\end{array}$ \\
\hline N-compounds & $\begin{array}{l}\text { N-ethyl-N'-nitroguanidine * } \\
\text { Pyrrole d,e,f }\end{array}$ \\
\hline $\begin{array}{l}\text { Phenols and } \\
\text { phenolic precursors }\end{array}$ & $\begin{array}{l}\text { Phenol a,b,c,f,g } \\
\text { Phenol, 2-methyl- a,b,c,f } \\
\text { Phenol, 4-methyl- a,b,c,f }\end{array}$ \\
\hline $\begin{array}{l}\text { Primary and } \\
\text { secondary } \\
\text { polysaccharides }\end{array}$ & $\begin{array}{l}\text { 2-Butanmine * } \\
\text { 2-Furancarboxaldehyde, 5-methyl- a,b,c,f } \\
\text { Acetic acid, 3,7,11,15-tetramethyl-hexadecyl ester d,e,f } \\
\text { Benzofuran, 2,3-dihydro- a,b,c,d } \\
\text { Furfural a,b,c,f }\end{array}$ \\
\hline
\end{tabular}


${ }^{a}$ White et al. (2002); ${ }^{\mathrm{b}}$ White et al. (2004); ${ }^{\mathrm{C}} \mathrm{Xu}$ et al. (2009);

* classification uncertain; ${ }^{\mathrm{d}}$ Vancampenhout et al. (2009);

e Yassir and Buurman (2011); ${ }^{\mathrm{f}}$ Carr et al. (2013); g Dai et al. (2002). 


\section{Figure Captions}

Fig. 1. Relative abundance (mean $\pm \mathrm{SD}$ ) of each soil organic matter (SOM) compound class in total detected pyrolysis products. The organic-rich sediments contained greater proportions $(\mathrm{p} \leq 0.05)$ of alkanes, alkenes, lignin products, and phenols and phenolic precursors than the remainder of the core.

| Fig. 2. Correlation coefficients between $\mathrm{CH}_{4}$ production potential rate at reference temperature of $3{ }^{\circ} \mathrm{C}$ and initial bulk SOM parameters. Correlations were determined using nonparametric Spearman's rank analyses. Statistically significant correlations $(\mathrm{p} \leq 0.05$ and $\mathrm{p} \leq 0.10)$ are denoted by bar color.

| Fig. 3. Ordination plots of PCA results. Diagram (a) plots PCA-I results from the sediment geochemistry data; diagram (b) shows PCA-II results from the bulk SOM compound class data. In both diagrams, the first PCs are plotted and we observe separation between the surface organic-rich sediments (circles; 0-152 cm depth in core) and the mineral sediments (triangles; $153-590 \mathrm{~cm}$ depth in core) Additional PCA results are presented in Table S.3. 


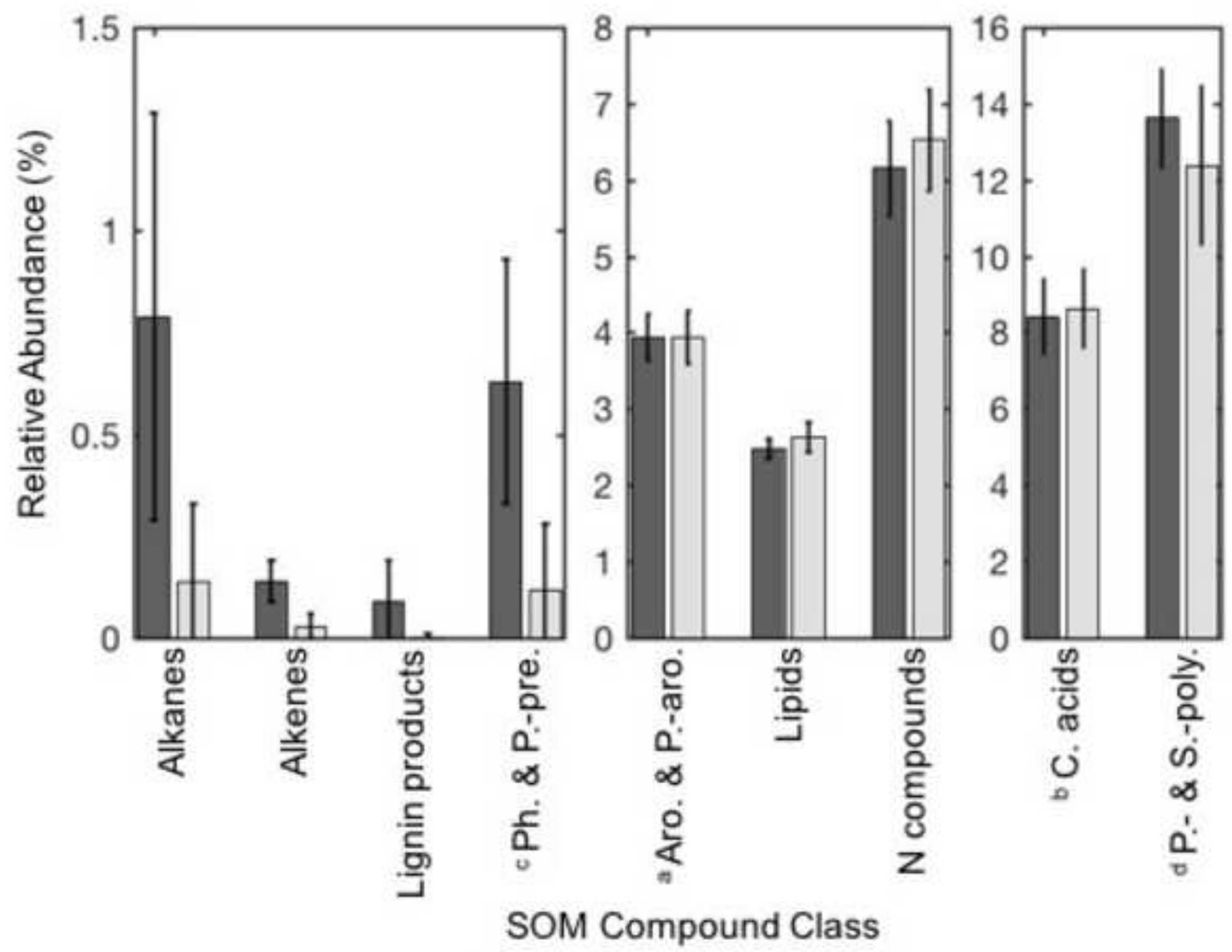

${ }^{a}$ aromatics and polyaromatics; ${ }^{b}$ carboxylic acids;

${ }^{\circ}$ phenolic and phenolic precursors; ${ }^{d}$ primary and secondary polysaccharides

$\square$ Surface organic-rich sediments

$\square$ Mineral sediments 


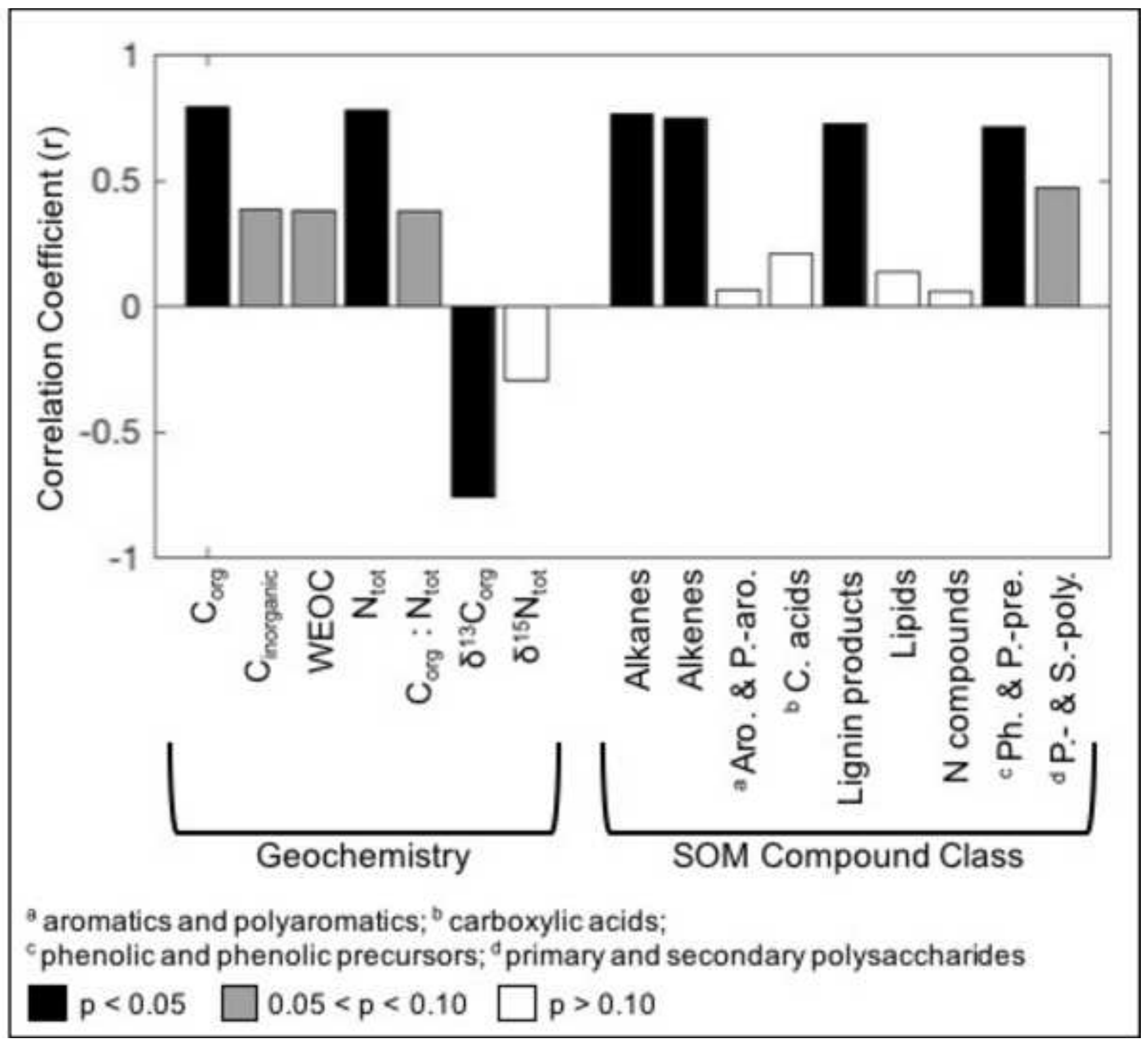



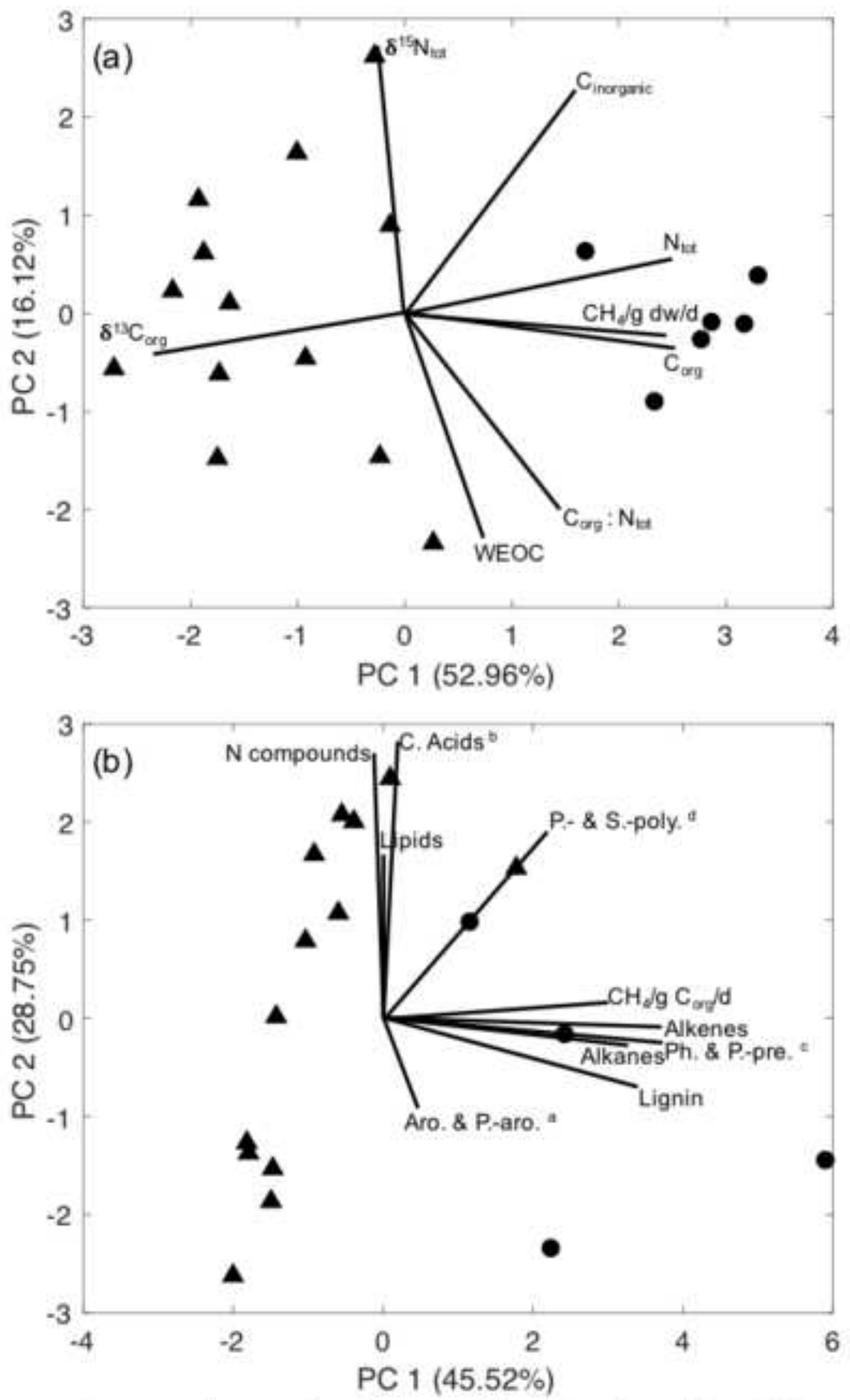

a aromatics and polyaromatics; ${ }^{b}$ carboxylic acids;

' phenolic and phenolic precursors;

${ }^{d}$ primary and secondary polysaccharides 

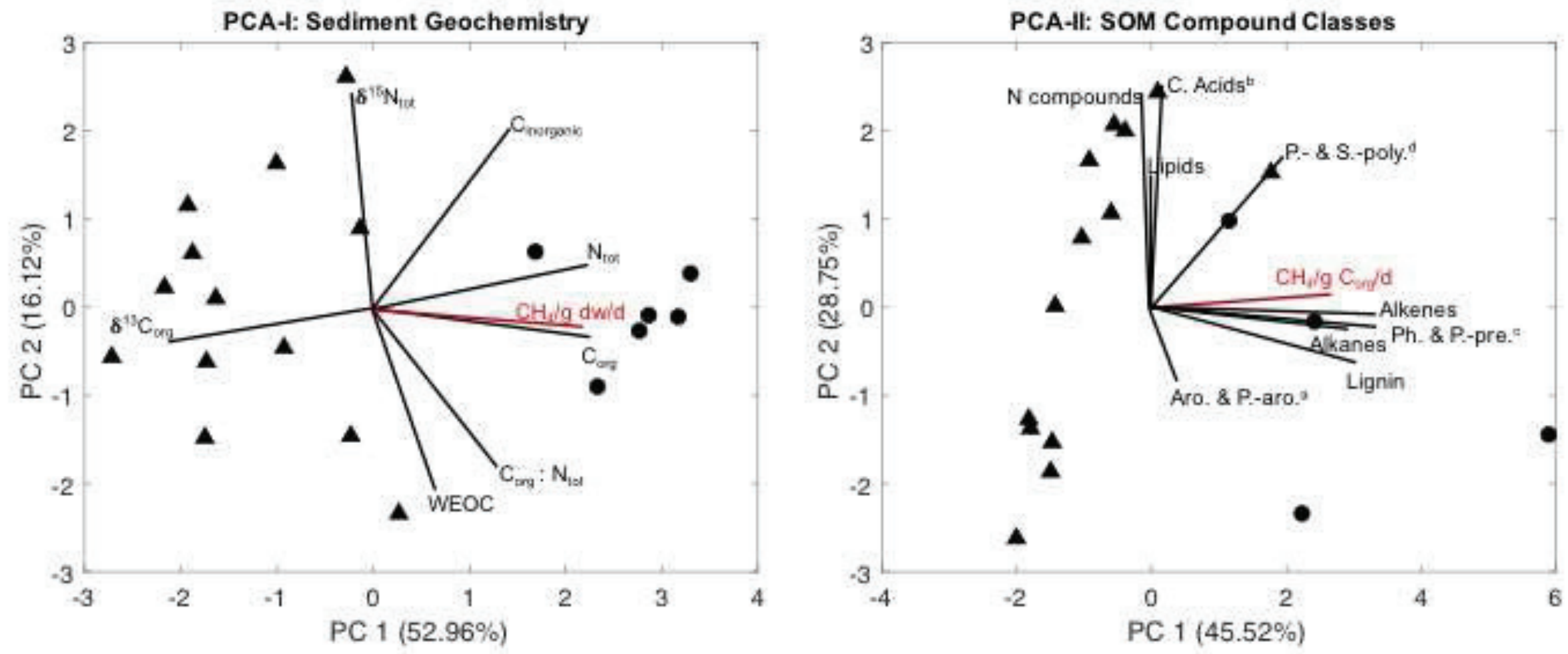

- Organic-rich sediments

" aromatics and polyaromatics;" carboxylic acids; ${ }^{\circ}$ phenolic and phenolic precursors

- Mineral sediments dprimary and secondary polysaccharides 